\title{
EHMTI-0348. Refractive errors in patients with migraine headache
}

\author{
A Gunes ${ }^{1 *}$, S Demirci ${ }^{2}$, L Tok ${ }^{3}$, O Tok ${ }^{3}$, HR Koyuncuoglu ${ }^{2}$, VA Yurekli ${ }^{2}$ \\ From 4th European Headache and Migraine Trust International Congress: EHMTIC 2014 \\ Copenhagen, Denmark. 18-21 September 2014
}

\section{Introduction}

Migraine is one of the most common debilitating diseases. Despite of intensive research in the pathogenesis and treatment of migraine, its relationship between refractive error have been controversial.

\section{Aims}

To evaluate refractive errors in patients with migraine headache and to compare with healthy subjects.

\section{Methods}

This prospective case-control study includes patients with migraine and age- and sex-matched healthy subjects. Clinical and demographic characteristics of the patients were noted. Then detailed ophthalmological examination were performed containing spherical refractive error, astigmatic refractive error, spherical equivalent (SE), anisometropia, best corrected visual acuity, intraocular pressure, slit lamp biomicroscopy, fundus examination, axial length, anterior chamber depth, and central corneal thickness. Spectacle use in migraine and control groups was compared. Also, the relationship between refractive components and migraine headache variables were investigated.

\section{Results}

Seventy-seven migraine patients with mean age of $33.27 \pm$ 8.84 years and 71 healthy subjects with mean age of 31.15 \pm 10.45 years were enrolled $(p=0.18)$. The migraine patients had higher degrees of astigmatic refractive error, $\mathrm{SE}$, and anisometropia when compared with the control subjects ( $\mathrm{p}=0.01, \mathrm{p}=0.03, \mathrm{p}=0.02$, respectively).

\section{Conclusions}

Migraine patients may have higher degrees of astigmatism, SE, and anisometropia. Therefore, they should have ophthalmological examination regularly to ensure that their refractive errors are appropriately corrected.

Seventy-seven migraine patients with mean age of 33.27 \pm 8.84 years and 71 healthy subjects with mean age of $31.15 \pm 10.45$ years were enrolled $(p=0.18)$. The migraine patients had higher degrees of astigmatic refractive error, $\mathrm{SE}$, and anisometropiawhencompared with the control subjects $(\mathrm{p}=0.01, \mathrm{p}=0.03, \mathrm{p}=0.02$, respectively).

No conflict of interest.

\section{Authors' details}

'Department of Ophthalmolgy, Süleyman Demirel University, Isparta, Turkey. 2Department of Neurology, Süleyman Demirel University, Isparta, Turkey.

${ }^{3}$ Department of Ophthalmology, Süleyman Demirel University, Isparta, Turkey.

Published: 18 September 2014

doi:10.1186/1129-2377-15-S1-M6

Cite this article as: Gunes et al.: EHMTI-0348. Refractive errors in patients with migraine headache. The Journal of Headache and Pain 2014 15(Suppl 1):M6.

Submit your manuscript to a SpringerOpen ${ }^{\odot}$ journal and benefit from:

- Convenient online submission

- Rigorous peer review

- Immediate publication on acceptance

- Open access: articles freely available online

- High visibility within the field

- Retaining the copyright to your article

Submit your next manuscript at $\boldsymbol{~ s p r i n g e r o p e n . c o m ~}$

\section{SpringerOpen $^{\circ}$}

@ 2014 Gunes et al; licensee Springer. This is an Open Access article distributed under the terms of the Creative Commons Attribution License (http://creativecommons.org/licenses/by/2.0), which permits unrestricted use, distribution, and reproduction in any medium, provided the original work is properly cited. 